\title{
CLIMATE CHANGE AND ITS IMPACT ON NEPALESE AGRICULTURE
}

\author{
G. Malla $(\mathrm{Msc})^{14}$
}

\section{ABSTRACT}

Exponential growth of $\mathrm{CO}_{2}$ and other greenhouse gasses in the atmosphere is causing climate change. It affects agriculture, forestry, human health, biodiversity, snow coverand aquatic to mountain ecosystems. Changes in climatic factors like temperature, solar radiation and precipitation have potentials to influence crop production. Despite many efforts possible on combating impacts of climate change, there are still difficulties in Nepalese agriculture. With an average of $0.06^{\circ} \mathrm{C} /$ yea, a rise in temperature from 1975 to 2006 by $1.8^{\circ} \mathrm{C}$ has been recorded in the country. Problem of frequent drought, severe floods, landslides and mixed type of effects in agricultural crops have been experienced in Nepal because of climate change. Study done on $\mathrm{CO}_{2}$ enrichment technology at Khumaltar revealed that the yield of rice and wheat increased by $26.6 \%$ and $18.4 \%$ due to double $\mathrm{CO}_{2}, 17.1 \%$ and $8.6 \%$ due to increase in temperature respectively. A crop simulation model (DSSAT) to study the effects of $\mathrm{CO}_{2}$, temperature and rain in NARC showed positive effect in yield of rice and wheat in all regions, but negative effect in maize especially in Terai. In Nepalese agriculture, the time has come for the authorities to find out adaptive measures to mitigate the effects to reduce untold natural calamities and miseries due to recent erratic weather pattern.

Key words: Agricultural crops, GHGs and $\mathrm{CO}_{2}$, temperature, precipitation

\section{INTRODUCTION}

\section{Climate change}

Climate change is a phenomenon due to emissions of greenhouse gases from fuel combustion, deforestation, urbanization and industrialization (Upreti, 1999) resulting variations in solar energy, temperature and precipitation. It is a real threat to the lives in the world that largely affects water resources, agriculture, coastal regions, freshwater habitats, vegetation and forests, snow cover and melting and geological processes such as landslide, desertification and floods, and has long-term affects on food security as well as in human health.

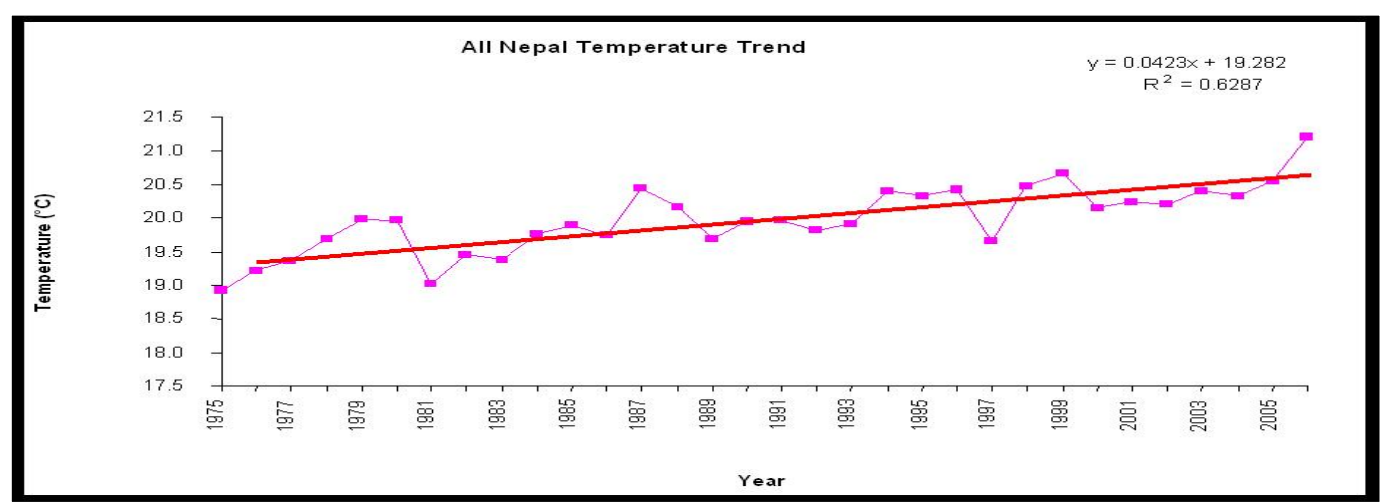

Figure 1: Trend of average annual max. temperature of Nepal (1975-2006)

\footnotetext{
${ }^{14}$ Agri Environment Officer, Agri Environment Unit, NARC. Email : gmalla@narc.gov.np
} 


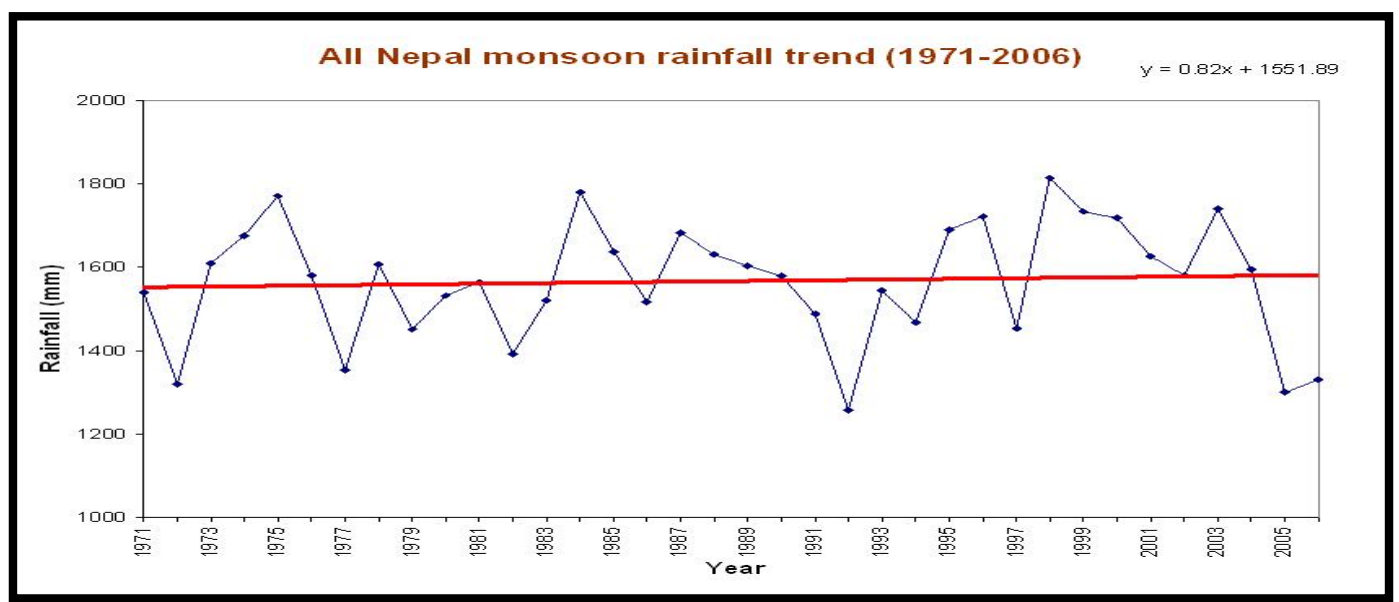

Figure 2: Trend of total precipitation (Source: Baidya and Karmacharya, 2007)

Fig. 1 shows the trend of average maximum temperature in Nepal, and that warming was higher than average in more than 12 years. Nepal's temperature has increased by $1.8^{\circ} \mathrm{C}$ during last 32 years. In Nepal average temperature increase was recorded as $0.06^{\circ} \mathrm{C}$ per year and that in Terai and Himalayas was $0.04^{\circ} \mathrm{C}$ and $0.08^{\circ} \mathrm{C}$ / year respectively (Shrestha et al., 1999). It may be due to solar radiation absorbed by glacial lakes as well as radiation absorbed by land because of snow melting in the Himalayan region.

Fig. 2 shows the trend of average rainfall in Nepal. It shows more erratic pattern of precipitation in the country. Rainfall was recorded minimum in the year 1972, 1977, 1992 and 2005 and maximum in the year 1975, 1985 and 1998 respectively. Erratic rainfall events (i.e. higher intensity of rains but less number of rainy days and unusual rain) with no decrease in total amount of annual precipitation have been experienced. Such events increase possibility of climatic extremes like irregular monsoon pattern, droughts and floods. For example, there were rain deficit in eastern terai and western regions, normal rain in far western region and heavy rain in the mid western region creating flood, landslide and inundation.

\section{Greenhouse gas and agriculture}

Water vapor, carbon dioxide $\left(\mathrm{CO}_{2}\right)$, methane $\left(\mathrm{CH}_{4}\right)$, nitrous oxide $\left(\mathrm{N}_{2} \mathrm{O}\right)$ and $\mathrm{CFCs}$ are the major gases that play important role in the greenhouse effect. Among the $\mathrm{GHGS} \mathrm{CO}_{2}, \mathrm{CH} 4$ and $\mathrm{N}_{2} \mathrm{O}$ are the 3 major gases which contribute about $88 \%$ roles in global warming (IPCC, 1996). Harrison and Aiyer noted the potential for $\mathrm{CH}_{4}$ release from rice fields as early as 1913 (Neue, 1993). Concentration of the $\mathrm{CH}_{4}$ gas in the atmosphere is presently increasing at the rate of $3 \%$ per year. It is predicted that by the year 2100 methane levels may rise by 3.0 to $4.0 \mathrm{ppm}$ that may have a significant effect on climate change. World Data Center of Greenhouse gases reported recent global abundance of $\mathrm{CO}_{2}, \mathrm{CH}_{4}$ and $\mathrm{N}_{2} \mathrm{O}$ is $377.1 \mathrm{ppm}, 1.783 \mathrm{ppm}$ and 318.6 ppb respectively (World Climate News, 2006).

Study conducted at Nepal Agricultural Research Council (NARC) at Khumaltar showed average seasonal methane emission from rice fields was $28 \mathrm{~kg} / \mathrm{ha} / \mathrm{season}$ in rain-fed condition and also found average maximum methane emission from rice field was $49.03 \mathrm{~kg} / \mathrm{ha}$ in the field supplied with $50 \%$ nitrogen $+15 \mathrm{~cm}$ stubble. Minimum of $7.7 \mathrm{~kg} / \mathrm{ha}$ of methane gas was found in the control fields. Further research on the GHGs in different eco-zones is required to quantify and verify their contribution more precisely in the agriculture (Malla, 2006). Seasonal 
methane emission of Thailand and India were 49 and $45 \mathrm{~kg} /$ ha respectively. Lower emission in Nepal was due to lack of irrigation facilities and minimum fertilizer application as compared to developed countries. Highest methane emission from rice was showed $367 \mathrm{~kg}$ in Korea. It may be due to maximum use of chemical fertilizer and better irrigation facilities.

Weather and agriculture

Weather is an atmospheric condition at the surface timescale from minutes to weeks and has an important impact on agriculture (ICIMOD/ UNEP, 2007). In Nepal, more than $80 \%$ of precipitation occurs in the monsoon during J une to September. Increase in temperature and vents of erratic rainfall directly affect the agriculture and food supply through their effects on crops. The production varies due to rain brought by monsoon. Agriculture is sensitive to short-term changes in weather that affect the production of crops. Insufficient rain and increasing temperature cause drought, whereas intense rain in short period reduces ground water recharge by accelerating runoff and causes floods. Both the situations induce negative effects in the agriculture. The climate change also causes disruption in normal weather pattern changing intensity and duration of monsoon.

Impacts on Nepalese agriculture

Nepal's economy depends on agriculture. Total area of Nepal is $147,181 \mathrm{~km}^{2}$ divided in mountains $(35 \%)$, hills $(42 \%)$ and terai $(23 \%)$. A total of 3091000 ha area is cultivated for agriculture, and it accounts for $38.15 \%$ of the gross domestic product (GDP). The country is susceptible to disasters, including flash flood, GLOF and melting snow in the mountains and droughts and inundation in the terai.

The rising temperature and emission of $\mathrm{CO}_{2}$ to some extent is helpful in production of major crops. For example, increase in agricultural production by enhancing photosynthetic processes, water use efficiency, shortening physiological period and soil microbial activities. Decrease in grain filling period due to increase in respiration process, fertilizer use efficiencies, shift in agricultural zone, increase in insect pest population, desertification, increase in soil erosion, evapo-transpiration and cause malnutrition in a world overflowing with food due to reducing protein and decrease in mineral nutrients content in different crops are negative effects. The impacts on agriculture are the decrease of productive land in some region and increase in other region. So, it is a complex problem to the world (Pathak et al., 2003a). Rising $\mathrm{CO}_{2}$ promotes plant growth and if the $\mathrm{CO}_{2}$ gas doubles, yields will increase by $40 \%$ Some positive findings with increased $\mathrm{CO}_{2}$ concentration are shown in the Annex 1 .

\section{EVIDENCES OF CLIMATE CHANGE IN NEPAL AND NEPALESE AGRICULTURE}

\section{General}

- Twelve warmest years since 1975 to 2007 (eg. 2006 was the warmest year)

- Late or pre-monsoon, unusual precipitation, decreased rainy days and intense rainfall events caused more runoff and low groundwater recharge.

- Extreme fog conditions have recently been observed in the terai regions.

- Traditional rainfalls of J estha and Ashar (mid J uly) have been shifted in Shrawan and Bhadra in Kathmandu. It has affected negatively in the paddy production. 
- Receding snowfall and retreating of the glaciers (AX010 small glacier mountain shrinking at alarming rate) due to increase in atmospheric temperature in mountain environment.

- KTM valley frost day decreasing, winter cold shifted to a month later than regular and snowfall in Kathmandu (Feb 2007, after 60 years).

- Recently Darchula district of the country faced unusual snow fall affecting collection of precious medicinal herbs Yarsa gumba (Kantipur news may 2008)

- Mosquito from Terai and Mid-hill being able to survive in high- hills (llam, Mustang and Helambu area)

\section{AGRICULTURE}

- Eastern Terai faced rain deficit in the year 2005/ 06 by early monsoon and crop production reduced by $12.5 \%$ on national basis. Nearly $10 \%$ of agri- land were left fallow due to rain deficit but mid western Terai faced heavy rain with floods, which reduced production by $30 \%$ in the year (Regmi, 2007).

- Early Maturity of the crops due to increase in temperature may help to have more crops in the same crop cycle (NARC annual report).

- Shifting of climatic zones has been observed in the country. Extinction of natural vegetation: local basmati rice varieties, some local wheat, maize and other agricultural crops was also observed.

- Cold wave in Nepal in 1997/98 had negative impacts on agricultural productivity and showed reduction in the production of crops by $27.8,36.5,11.2,30,37.6$ and $38 \%$ in potato, toria, sarson, rayo, lentil and chickpea respectively (Source: NARC annual reports from 1987/ 88 to $1997 / 98$, ).

\section{OBJ ECTIVES}

- To introduce the concept of climate change and its impacts in agriculture

- To help policy makers in formulating strategies on climate change and its consequences

\section{IMPACT OF CLIMATE CHANGE ON AGRICULTURAL LANDS AND AGRO-ECO-ZONES}

Nepal has various types of agricultural zones like plains, hills, mid hills, high hills and mountains. Changes in agri-zones lead to the change in cropping pattern of the zone. Climatic parameters have potential impact to change the ecological distribution of agricultural crops. If shifting of climatic zones occurred rapidly due to climate change, extinction of biodiversity might be severe. Effects are mainly on cold-water fish, herbs, pasturelands, tree lines (apple trees) and livestock (Chauri). Increase in temperature cause more damage on agricultural sectors in Terai region and will be more favorable to agriculture in the hills and mountains. As temperature increases, cropping pattern as well as vector born disease of human and livestock's can be expected to shift in higher eco zones too. Some lands, which are presently undesirable due to different weather factors, may be desirable in near future. For example: maize, chilly, tomato and cucumber are now being adopted in Mustang district of the country.

Soil fertility and water availability

As a natural fertilizer, more food can be grown with increasing $\mathrm{CO}_{2}$. Increase in vigorous growth of food crops due to more availability of $\mathrm{CO}_{2}$ may reduce the nutrients available in soil. Increase in temperature may lead to reduce the level of soil organic carbon, soil 
micronutrients and enhance decomposition by activating the microbial population in the soil (Malla, 2003). Koshi, Narayani, Karnali and Mahakali are four major rivers flowing from the Himalayas, and are the main source of water of the country. Agricultural sectors: mainly crops, livestock's and horticulture largely depend on the given water sources in the country. Variability in climate and weather is major reason for change in moisture availability in the soil. The rapid evapo-transpiration due to increase in temperature, will demand more water to reduce drought. Water availability governs the physiological active period and crop production. Research showed evapo-transpiration and evaporation were also disturbed by $+2^{\circ} \mathrm{C}$ and $+4^{\circ} \mathrm{C}$ monthly temperature rise (Fennessey, 1994). Probable vulnerabilities due to increase in atmospheric temperature are decrease in watertable, increase in evapotranspiration, soil erosion, landslides, floods, inundation of standing crops and reduction of soil fertility.

\section{IMPACTS OF CLIMATE CHANGE ON MAJ OR CROPS AND LIVESTOCK}

Rice

Rice is the second important crop in the world with production of about 525 million tons from about 148 million hectors. It is cultivated within an altitude of 300-2300 meter above sea level. In south Asia, rice production has to be doubled by the year 2020 (IRRI, 2000). Study on increased $\mathrm{CO}_{2}$ and temperature in NARC at Khumaltar shows the increase of rice yield by 17.07 and $26.58 \%$ even at the increase in temperature in chamber by $6.2^{\circ} \mathrm{C}$ and $7.36^{\circ} \mathrm{C}$ (Annex 2 and 3). Greenhouse effect due to doubling carbon dioxide was observed by $1.16^{\circ} \mathrm{C}$ and produced $9.51 \%$ higher than ambient plots. Nitrogen content of the rice was increased by $16.3 \%$ due to rise in temperature, but decreased by $9.8 \%$ due to doubling of $\mathrm{CO}_{2}$. Panicle initiation, flowering, heading, milking stage and crop maturity period has decreased by $7,4,4,4$, and 6 days respectively due to the increase in temperature.

Crop simulation modeling "Decision Support System for Agro-technology Transfer" (DSSAT) was used with $\mathrm{CO}_{2}$, temperature and rain as climatic parameters to study impact of climate change in rice, wheat and maize in NARC and showed that the rice yield increased under elevated $\mathrm{CO}_{2}$ in the terai, hills and mountains initially. But it dropped to $3.4 \%$ in the terai, and continued to increase by $17.9 \%$ in the hills and by $36.1 \%$ in the mountains, when the temperature was increased by $4^{\circ} \mathrm{C}$ (Fig 3 ).
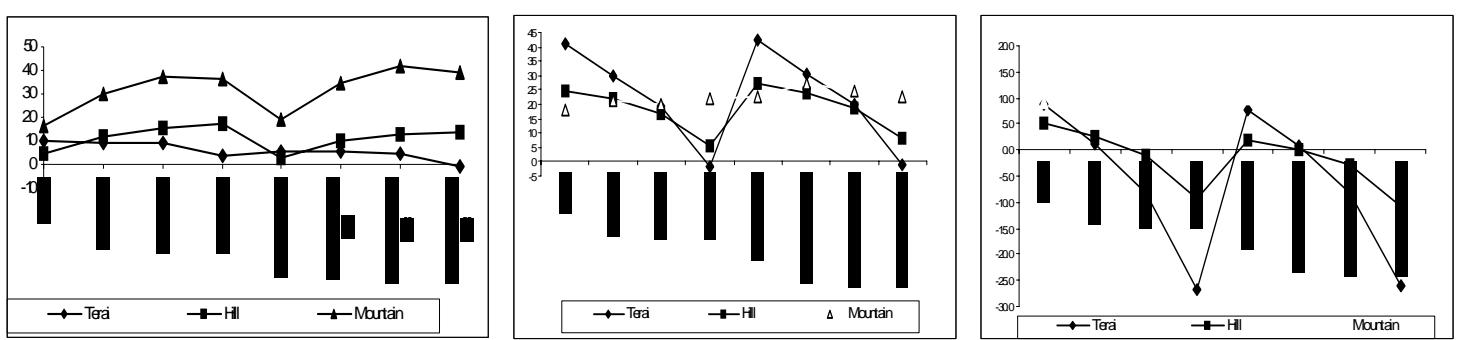

Figure 3: Percentage change in rice, wheat and maize yield with $\mathrm{CO}_{2}$, temperature and rain (source: Sherchand et al., 2007) 
Wheat

Wheat is the first important crop in world and third in Nepal. It occupies $20 \%$ of total cereal area and contributes $18.8 \%$ of the total cereal production in the country. Climatic parameters like rain and temperature strongly affect the growth and productivity of wheat. An experiment conducted in Open Top Chamber at Khumaltar shows the increase of wheat yield by 8.63 and $9.74 \%$ even at the increase of the temperature by $6.94^{\circ} \mathrm{C}$ and the doubling of $\mathrm{CO}_{2}$ (Annex 4 and 5). Greenhouse effect due to doubling of $\mathrm{CO}_{2}$ was observed only by $0.18^{\circ} \mathrm{C}$ and produced $9.74 \%$ higher than ambient plots. Physiological growth stages like panicle initiation, heading, flowering, milking and physiological maturity decreased by 14, 5, 9, 6 and 14 days respectively due to increase in temperature. Increase in the $\mathrm{CO}_{2}$ level in the $\mathrm{C}_{3}$ pathway in rice and wheat helped to increase the production.

Wheat production was increased by $41.5 \%$ in the Terai plain, $24.4 \%$ in the hill and $21.2 \%$ in the mountain under the elevated $\mathrm{CO}_{2}$. The yield however decreased by $1.8 \%$ in the Terai but continued to increase by $5.3 \%$ in the hill and $33.3 \%$ in the mountain at $4^{\circ} \mathrm{C}$ rise in temperature under irrigated condition (fig.3). The study conducted in India showed that, in subtropical region there will be small decrease in potential yield by $1.5-5.8 \%$ but in tropical zone the decrease will be $17-18 \%$ (Agrawal and Kalra, 1994). It indicates that rainfed wheat productivity is likely to suffer more in Terai as compared to the mid-hill's environment in a climate change scenario. The additional rains had favorable impacts on the wheat yield at all levels of temperature rise (Sherchand et al., 2007).

Maize

Maize is second major crop in Nepal but the primary crop in the hills. Soil moisture availability during pre-monsoon determines the planting date of maize. The relaying or mixed cropping in the hills are common practices to ensure harvest of the crop. The millet and soybean is widely relayed at mid-altitude whereas groundnut and beans are also used as relay crops for maize. Being a $\mathrm{C}_{4}$ photosynthetic pathway plant, its grain productivity is less responsive to impacts of increase in atmospheric $\mathrm{CO}_{2}$ level. Maize production was increased by $9.0 \%$ in the terai, $4.9 \%$ in the hills and $15.5 \%$ in the mountains. However, the yield continued to decline by $26.4 \%$ in the terai, by $-9.3 \%$ in the hills but increased to $26.8 \%$ in the mountains at $4^{\circ}$ temperature rise. Thus, the response of temperature to maize crop is more favorable in the mountains than in the terai and hills.

\section{Horticultural crops}

Fruits and vegetables are grown in 255 thousand hectares. Climate change effects on horticultural crops are speedily becoming issues in the present situation. Tropical fruits (banana, mango, papaya) and other crop like (croton) has been adopted in mid hills and observed off-season flowering in high altitudes crops like peach, pear and apple. Open top chamber was used to study the response of temperature and $\mathrm{CO}_{2}$ in tomato and showed that tomato production increased by $279 \%$ and fruit number by $205 \%$ in increased $\mathrm{CO}_{2}$ as compared to field condition (Annex 6).

Some researches conducted in other countries has shown doubling of $\mathrm{CO}_{2}$ in potato decreased the elements content like iron, zinc, manganese and sulphur. In soybean seed Oleic acid concentration increased with increase in temperature whereas linolenic acid decreased (Thomas et al., 2003). Also researches showed complex results e.g. in strawberries ascorbic 
acid and glutathione increased by 13 and 171 percent from ambient to ambient $+600 \mathrm{ppm}$ $\mathrm{CO}_{2}$ condition (Agriculture Research Service). Etween, 1993 found 14 per cent decline in nitrogen content of seeds compared with plants grown in ambient air (Curtis). Seventy-five percent increase in air $\mathrm{CO}_{2}$ content increased sourness in orange. Vitamin $\mathrm{C}$ (antioxidant) was increased approximately by 5 percent due to increase in carbon dioxide gas (Kimball and Mitchell, 1981). Increase in $\mathrm{CO}_{2}$ in atmosphere makes positive impacts in the amount of essential vitamins in fruits and vegetables that help to improve the human health.

\section{Pests and diseases}

Climate change parameters: temperature, rainfall pattern and humidity have an impact on the development and distribution of pests and diseases. Increase in temperature and $\mathrm{CO}_{2}$ will lead to an increase in population of pests and severity of diseases in presence of host plant. It increases the rate of reproductive cycle of insect and pest. The increase in insect population leads to demand for more use of pesticide, which unknowingly causes lots of harm to ecosystem as well as human society. Incidence of pest and diseases would be most severe in tropical region due to climate change. Pest and disease of plain ecosystem may gradually shift to hills and mountains. Some pathogens of important crops from Terai zones has adapted in hills and mid-hills (eg. rust and foliar blight) that may adversely affect the agricultural production.

\section{Livestock}

Livestock is a major component of agriculture. It includes poultry, dairy production and raring animals such as cattle, buffaloes, sheeps, goats and pigs. It is the major contributor of methane mainly from ruminant animals. It is estimated to be around $365.78 \mathrm{Gg}$ from 19.4 million animals in Nepal. Meat and milk products are perishable goods, which require more energy to conserve the products. It is highly sensitive to fluctuation of atmospheric temperature. Increase in temperature by $2^{\circ} \mathrm{C}$ would decrease the meat and milk quality, hatchability of poultry and increases the possibility of disease in the livestock. Thus, it increases the probability of vector born diseases in the human society. On the other hand, increase of atmospheric $\mathrm{CO}_{2}$ will increase the greenery of the land or fodder and pasture for the livestock's. Increase in amount of green fodder helps to boost up meat and milk production. It will ultimately help in improvement of economic status of Nepalese livestock farmers. However, if $\mathrm{CO}_{2}$ is increases rapidly, all the living creatures have to suffer from various impacts like diseases and other problems.

\section{RESEARCH POTENTIALS OF NEPALESE AGRICULTURE TO ADAPT IN THE CHANGING CLIMATE}

- Improvement of heat, drought and pest resistant crops

- Improvement in resources for irrigation efficiencies: drip and sprinkler irrigation

- Research in water and nutrient management in various agro-ecologies to meet the climate change

- Research in green manuring crops, cover crops, to preserve soil moisture, soil organic matter and micronutrients

- Research on climate prediction related models and their application.

- Research works on new technologies towards low carbon economy.

- Research on land use planning, watershed management, vulnerability assessment and resource management.

- Research on yield gap analysis to analyze the factors responsible to climate change 


\section{STRATEGIES FOR IMPROVNG THE AGRICULTURAL PRODUCTIONS}

- Promote seminar, workshops, training and general education to rural population dependent on agriculture.

- Identification of present issues of climate change related to agricultural sectors.

- Strengthen Agricultural Research Station and commodity program to run effective researches related to climate change.

- Interactive communication for transfer technologies to farmers about climate change and its impacts on agriculture

- Preservation of genetic materials to reduce extinction of biodiversity

- Crop insurances for social securities and food securities

- Change in national policies towards farmers incentives such as subsidy in agricultural inputs and agricultural investment

\section{RECOMMENDATIONS}

The following important recommendations should get priority in policy:

- Develop irrigation infrastructure for reducing drought hazards.

- Develop minimum tillage and zero tillage in the rice, wheat and maize to reduce carbon and water loss from soil.

- Develop heat, drought resistant verities/breeds, insect pest resistant varieties and increase mechanism of IPM (integrated pest management)

- Develop safe agrochemicals to minimize pest and disease damage in the crops.

- Develop cooperation and coordination with neighboring country to cope with vulnerabilities.

- Develop climate-forecasting system for reducing hazards.

\section{CONCLUSION}

Climate change is real and underway, so there is a need of impact identification and adoption to cope with vulnerabilities in agricultural sector. Nepal being a least developed country, it is moving towards vulnerable situation due to climate change. As it is known, its effects cannot be completely controlled but effective planning and change in human habit towards a low carbon economy can slower down possible disasters. Enriched $\mathrm{CO}_{2}$ has shown positive impact on yield of maj or crops in all geographical zones. However, some research findings from other countries showed reduction in grain and food quality. Increase in temperature and $\mathrm{CO}_{2}$ levels is also threatening to bring hidden-hunger problem in human by lowering essential nutrients contents in food crops. It is concluded that overall impact of climate change in agricultural sectors will have negative impacts in the long run.

\section{REFERENCES}

AEU, 2001. Agri Environment Unit Annoal Report, 2001.

Agrawal, P. K. and N. Kalra, 1994. Analysing the limitation set by climate factors, genotype, and water and nitrogen availability on productivity of wheat II. Climatically potential yield and optimal management strategies. Field crop res. 38:93-103

Agriculture and Environment, 2000. Global warming and its relationship with agriculture. 
Baj racharya, et al., 2007. Impact of climate on Himalayan glaciers and glacial lakes. ICIMOD/ UNEP, pp7-19.

Fennessey, N. M. and P. H. Kirshen, 1994. Evaporation and evapo-transpiration under climate change in New England.

ICIMOD, UNEP, 2007. Global Climate Change and Retreat of Himalayan Glaciers in China, India, Bhutan and Nepal, pp7-19.

IPCC, 1996. Climate Change - 1995. The Science of Climate Change. Cambridge (UK): Cambridge University Press, XII, pp572

IRRI, 2000. world rice statistics 1993-1994. International rice research Institute, manila, The Philipines

Lawton, 2002. New scientist vol 176issue2371-30 November2002. page 26

Malla, G. et al., 2005. Mitigating nitrous oxide and methane emission from soil in rice-wheat system of the Indo-Gangetic Plain with nitrification and urease inhibitors, Chemo- sphere, 58:141-147.

Malla, G., 2003. Impact of climate change on water and soil health, Agriculture and Environment. MOAC, pp63-71.

Malla, G., 2006. Effect of different fertilizers in reducing Methane gas $(\mathrm{CH} 4)$ emission from rice fields. Summer crop workshop proceeding,

Malla, G., 2007. Melting Ice: ' warning signs' , The J ournal of Agriculture and Environment. MOAC, pp66-73.

Malla, G., 2007. Methane emission is challenge for environment. Hamro Sampada. Indreni offset press, pp1172-173.

Neue, H.U., 1993. Methane emission from rice fields. Bioscience, 43: 466-474. Prinn, R.G. (1995) Global Change: Problems and uncertainties. In: Peng, S., Ingram,

Pathak, et al., 2003a. Climate potential and onfarm yield trends of rice and wheat in the indo Gangatic plains field crops Re, 80:223-234.

Pathak. H. and S. Kumar, 2003. Soil and greenhouse effect monitoring and mitigation: CBS publishers and Distributors.

Regmi, H. R., 2007. Effect of unusual weather on cereal crops production and household food security. The J ournal of Agriculture and Environment, pp20-29

Sherchand, et al., 2005. Carbon dioxide enrichment technology in rice.

Sherchand, et al., 2007. Climate Change and Agriculture In Nepal J uly 2007. DSSAT

Sherwood, et al,. 2007. Enhanced Impared ? Human Health in a Co2 - Enriched warmer world. http:// www. co2science.org

Shrestha, et al., 2002. Bathymetric surver of Tsho Rolpa Glacier Lake-2002.

State of the Environment, 2001. United Nations Environment Program, pp11-22.

The J ournal of the Agriculture and Environment, 2007, Melting Ice: A Hot Topic, MOAC, pp20-29.

Thomas, et al, . 2003. Elevated temperature and carbondioxide effects on soybean seed composition and transcript aboundance. Crop science society of America, 43:1548-1557.

Upreti, C. R., 2007. A technology for reducing methane from livestock's. Hamro Sampada. Indreni offset press, pp102-103.

Upreti, D.C., 1999. Rising Atmospheric CO and crop response. SASCOM Scientific Report, pp1-8.

World Climate News, 2006. Homing in on rising sea-leavels. J une 29, 2006.

\section{ANNEXES}


Annex 1: Percentage increase in agricultural crops due to double $\mathrm{CO}_{2}$

\begin{tabular}{l|l|l}
\hline S.N & Agricultural crops & \%increase in productivity \\
\hline 1 & $\mathrm{C}_{3}$ cereals & 70 \\
2 & $\mathrm{C}_{4}$ cereals & 28 \\
3 & Fruits and melons & 33 \\
4 & Legumes & 62 \\
5 & Roots and tubers & 67 \\
6 & Vegetables & 51 \\
7 & Mean & 51.83 \\
\hline
\end{tabular}

Source: Science and technology news service, vol. 176, issue2371, Nov, 2002

Annex 2: Rice yield and \%change due to increase in $\mathrm{CO}_{2}$ and temperature

\begin{tabular}{|c|c|c|c|c|c|c|}
\hline \multirow{2}{*}{ Treatment } & \multicolumn{6}{|c|}{ Rice Yield $(\mathrm{kg})$} \\
\hline & 2001 & 2002 & 2003 & 2004 & Average & \%Change \\
\hline Ambient+elevated $\mathrm{CO}_{2}$ & 10857 & 11966 & 9861 & 8918 & 10400.5 & $26.58(9.51)$ \\
\hline Ambient & 6860 & 11392 & 9395 & 8110 & 8939.25 & 17.07 \\
\hline Field & 6386 & 10334 & 6794 & 7028 & 7635.5 & \\
\hline
\end{tabular}

Annex 3: Average maximum temperatures during rice season

\begin{tabular}{l|l|l|l|l|l|l|l}
\hline \multicolumn{7}{l}{ Maximum Temperature ${ }^{\circ} \mathrm{C}$} & during rice crop \\
\hline Treatment & 2001 & 2002 & 2003 & 2004 & 2005 & Average & Difference \\
CO2 Enrichment & 35.84 & 31.59 & 35.76 & 35.34 & 35.1 & 34.726 & $7.36(1.16)$ \\
Ambient & 34.29 & 30.5 & 34.43 & 34.5 & 34.1 & 33.564 & 6.2 \\
Field & 27.43 & 26.16 & 28.63 & 27.2 & 27.4 & 27.364 & \\
\hline
\end{tabular}

Source: AEU annual report, 2001

Annex 4: Wheat yield and \%change due to increase in temperature

\begin{tabular}{l|l|l|l|l|l|l}
\hline \multirow{2}{*}{ Treatments } & Wheat Yield $(\mathrm{kg})$ \\
\cline { 2 - 7 } & $2001 / 02$ & $2002 / 03$ & $2003 / 04$ & $2004 / 05$ & Average & $\%$ Change \\
\hline $\mathrm{CO}_{2}$ Enrichment & 3059 & 5644 & 4100 & 4380 & 4296 & $18.37 \%(9.74)$ \\
Ambient & 2235 & 5420 & 2800 & 4897 & 3838 & $8.63 \%$ \\
Field & 1132 & 5037 & 3100 & 4758 & 3507 & \\
\hline
\end{tabular}

Annex 5: Average maximum temperatures during wheat season

\begin{tabular}{l|l|l|l|l|l}
\hline \multirow{2}{*}{$\begin{array}{l}\text { Treatments } \\
\text { Year }\end{array}$} & \multicolumn{4}{|l}{ Maximum Temperature ${ }^{\circ} \mathrm{C}$ during wheat crop } \\
\hline CO2 Enrichment & $2002 / 03$ & $2003 / 04$ & $2004 / 05$ & Average & Difference \\
Ambient & 24.91 & 30.06 & 28.1 & 27.69 & $7.12(0.18 \%)$ \\
Field & 26.06 & 29.07 & 27.4 & 27.51 & 6.94 \\
\hline
\end{tabular}

Source: AEU annual report, 2001

Annex 6: Percentage change in Tomato yield by doubling $\mathrm{CO}_{2}$ and rise of temperature

\begin{tabular}{l|l|l|l}
\hline Treatment & Fruit Wt. (kg/ ha) & Fruit Wt. \% & Fruit No. \% \\
\hline Elevated $\mathrm{CO}_{2}$ & 22451 & 279 & 205 \\
Ambient & 15785 & 196 & 165 \\
Field & 8032 & 100 & 100 \\
\hline
\end{tabular}

